\title{
Coastal sand dune flora in the Thoothukudi District, Tamil Nadu, southern India
}

\author{
K. Muthukumar ${ }^{1} \&$ A. Selvin Samuel ${ }^{2}$ \\ ${ }^{1}$ No. 9B, Keelakottai, Gangaikondan-via, Tirunelveli, Tamil Nadu 627352, India, \\ ${ }^{2}$ Department of Plant Biology and Plant Biotechnology, St.John's College, Palayamkottai, Tamil Nadu 627007, India \\ Email: ${ }^{1}$ muthukumarbut1976@yahoo.com (corresponding author), ${ }^{2}$ selvinsml@yahoo.com
}

\begin{abstract}
Coastal sand dunes (CSD) are found in the Thoothukudi District and the communities living close to the coastal sand dunes know the value of the sand dunes and their bioresources. A study of sand dune flora along coastal sand dune areas was done from March to August 2010. A total of 42 species belonging to 38 genera and 26 families were identified at different distances from the shoreline. The CSD systems are rich and diverse in their floral composition, even over the small areas of Manapadu and Kulasakarapattanam along the Thoothukudi coastal line. CSD constitute a variety of habitats and have vital ecological and economic importance. Such unique sensitive systems have to be protected from habitat degradation in order to protect their native diversity and ecological functions.
\end{abstract}

Keywords: Coastal sand dunes, ecological, Manapadu, Kulasakarapatinam, Tuticorin.

Coastal sand dunes (CSD) are common in different parts of the world. CSD are natural structures protecting the coast from high waves and saltwater intrusions (Corre 1991). The plants living in sand dunes are called Psammophytes. These psammophytic species play a vital role in protecting the coast from erosion and floods (Desai 2000). The coastal length of

Date of publication (online): 26 November 2011

Date of publication (print): 26 November 2011

ISSN 0974-7907 (online) | 0974-7893 (print)

Editor: Anonymity requested

\section{Manuscript details:}

Ms \# 02634

Received 25 November 2010

Final received 10 October 2011

Finally accepted 02 November 2011

Citation: Muthukumar, K. \& A.S. Samuel (2011). Coastal sand dune flora in the Thoothukudi District, Tamil Nadu, southern India. Journal of Threatened Taxa 3(11): 2211-2216

Copyright: @ K. Muthukumar \& A. Selvin Samuel 2011. Creative Commons Attribution 3.0 Unported License. JoTT allows unrestricted use of this article in any medium for non-profit purposes, reproduction and distribution by providing adequate credit to the authors and the source of publication.

Acknowledgements: Authors are grateful to Mr. T. Mallikaraj and J. Sundher for his encouragement for during the field survey. We also thank the anonymous reviewers whose comments improved this manuscript substantially.

\section{OPEN ACCESS I FREE DOWNLOAD (C) (i) @}

India is $7500 \mathrm{~km}$ with many lagoons, beaches, estuaries, and mangrove swamps, supporting rich biotic and abiotic micro-organisms (Anonymous 1987). With respect to geographic location and physical distinctiveness, the coast of Thoothukudi District is part of the Gulf of Mannar Biosphere Reserve (08 $45^{\prime} 36^{\prime \prime}-$ 9002'31'N \& 7807'17'-78 $18^{\circ}$ '18'E). The recorded forest area is $169 \mathrm{~km}^{2}$, which constitutes $3.66 \%$ of the geographic area of the district (Forest Survey Report 2005). There are different types of vegetation on the coast of Thoothukudi, this includes mangroves and their associates - scrub jungles, aquatic vegetation, and coastal sand dune vegetation. A sand dune is a mound, hill or ridge of sand that lies behind the part of the beach affected by tides. They are formed over many years when windblown sand is trapped by beach grasses. Dune grasses anchor the dunes with their roots, holding them temporarily in place, while their leaves trap sand, promoting dune expansion. The sand dune is maintained with the help of sand dune vegetation as wind traps, sand binders and dune stabilizers (Wagner 1964). Temperate coastal dunes are well studied and documented (Koske \& Gemma 1997; Sridhar \& Bhagya 2007) as compared to studies on tropical coastal dunes (Kulkarni et al. 1997; Sridhar \& Bhagya 2007). CSD comprise a variety of flora and fauna, which play a vital role in provisioning ecological and economical services to the coastal communities (Maun \& Baye 1989; Martinez et al. 1997). The coastal communities closely associated with sand dune habitats are dependent on CSD vegetation for a variety of benefits: for food, fodder, health, manure and recreation. In fact, very few publications are available on the floral diversity of Indian sand dunes (Sridhar $\&$ Bhagya 2007). The objective of the present study was to quantify the abundance, species richness and diversity of the CSD plant community, to understand their ecological and economic importance to the lo- 
cal community of Manapadu and Kulasakarapattanam coastline of Thoothukudi District, Tamil Nadu.

\section{Materials and Methods}

Study area: Thoothukudi is located on the southeastern coast of Tamil Nadu ( $8^{0} 37^{\prime} 15^{\prime \prime}-8^{0} 39^{\prime} 97^{\prime}$ 'N \& $78^{\circ} 06^{\prime} 24^{\prime}-78^{\circ} 05^{\prime} 96$ 'E; Fig. 1). Manapadu and Kulasakarapattanam are coastal villages with sand dune coverage of about $3 \mathrm{~km}^{2}$ and $4 \mathrm{~km}^{2}$ extent respectively. The coastal border has a length of $20 \mathrm{~km}$ and a breadth ranging from 3 to $500 \mathrm{~m}$. Superficially, the coast is flat and sandy. The study area experiences a mean annual temperature of $32^{\circ} \mathrm{C}$ and a mean annual rainfall of $655 \mathrm{~mm}$ and humidity $87 \%$. The mean monthly temperature ranges from $29-35{ }^{\circ} \mathrm{C}$. The climate is tropical and dissymmetric with the bulk of the rainfall occurring during the northeast monsoon October-December (Thoothukudi District website). CSD formations depend on accumulating size and prevailing wind energy (Kumar et al. 1993). Their height differs in response to the availability of sand supply, climate and local topographic features (Barbour et al. 1985). In Mana-

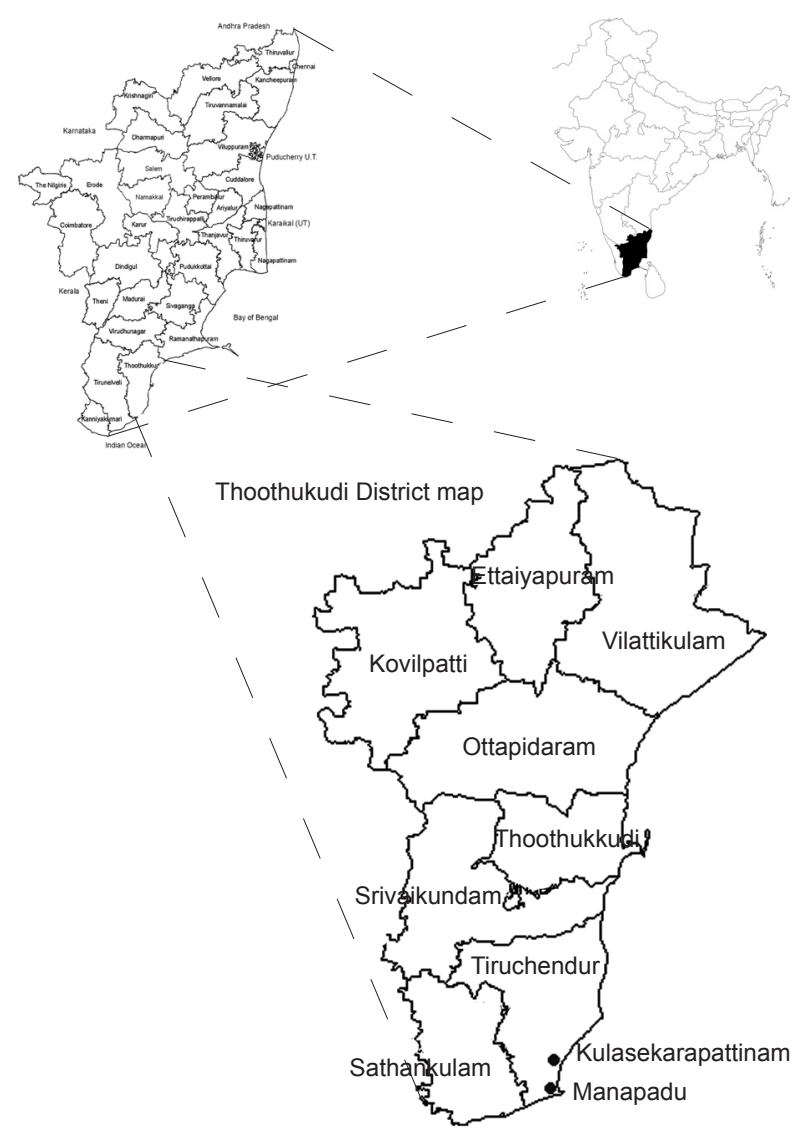

Figure 1. Study area

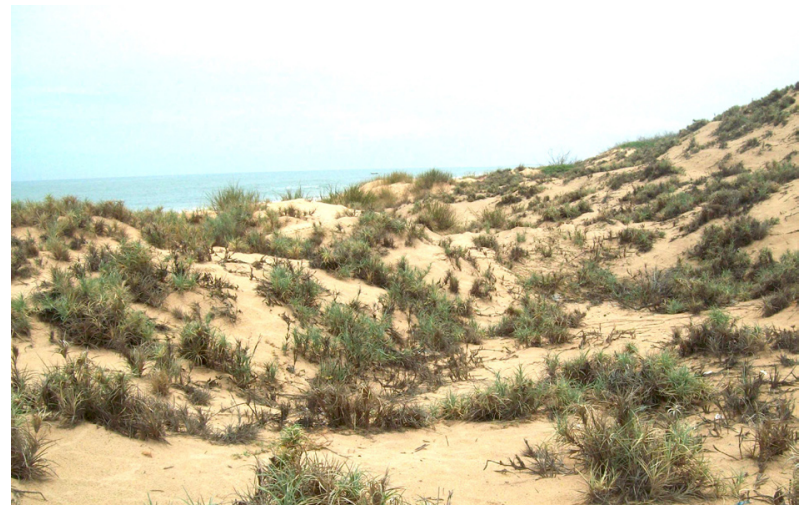

Image 1. Sand dune in Manapadu Village

padu the height of the sand dunes is very high $(35 \mathrm{~m}$; Image 1) compared to Kulasakarapattanam (6.4m).

Data collection: A total of 10 quadrates of $5 \times 5$ $\mathrm{m}$ were marked randomly in 10 locations at different distance gradients from the shoreline in each village. Every plant species found along the 10 quadrates was enumerated. Species (Table 1) were identified by using published flora (Daniel \& Umamaheswari 2001; Banerjee et al. 2002).

\section{Results \& Discussion}

In the study area 42 species belonging to 38 genera representing 26 families were enumerated during this survey. Out of the total Indian CSD plants listed so far (154), nearly one-third (42) of them were recorded in the study area. Indian CSDs consist of 154 species belonging to 108 genera and 41 families (Arun et al. 1999; Rao \& Sherieff 2002). The Poaceae family was most common and dominant with five species followed by Malvaceae (4), Asteraceae (3), Euphorbiaceae (3), Cyperaceae (2), Amaranthaceae (2), and Arecaceae (2). Nineteen families were represented only by one species, and over all 25 were medicinal plants (Table 1). Several authors have pointed out that the temperate CSD comprise mainly the members of Poaceae, and the tropics with Asteraceae, Cyperaceae, Fabaceae and Poaceae (Arun et al. 1999; Rao \& Sherieff 2002; Sridhar \& Bhagya 2007). During the present study Poaceae, Malvaceae, Asteraceae, Euphorbiaceae, Cyperaceae were the most common families. Many authors have mentioned that in various parts of the world many dune ecosystems support high plant richness and diversity values (Musila et al. 2001; Grootjans et al. 2004; Fontana 2005; Celsi \& Monserrat 2008). The present study also indicates that 
Table 1. The list of sand dune flora from Tuticorin coast

\begin{tabular}{|c|c|c|c|c|c|}
\hline & Scientifice name & Family & Habit & Tamil Name & Uses \\
\hline 1. & Abutilon indicum (L.) Sweet. & Malvaceae & Shrub & Thuthi & - \\
\hline 2. & Acalypha indica L. & Euphorbiaceae & Herb & Kuppaimeni & + \\
\hline 3. & Acanthospermum hispidum DC. & Asteraceae & Herb & Kombu mull & + \\
\hline 4. & Aerva persica (Burm.f.) Merr. (Image 2) & Amaranthaceae & Shrub & Perumpulai & + \\
\hline 5. & Aristida setacea Retz. & Poaceae & Herb & - & $E$ \\
\hline 6. & Atriplex repens Roth. & Chenopodiaceae & Herb & - & - \\
\hline 7. & Azadirachta indica A. Juss. & Meliaceae & Tree & Veppamaram & + \\
\hline 8. & Boerhavia diffusa $\mathrm{L}$. & Nyctaginaceae & Herb & Mukurattai & + \\
\hline 9. & Borassus flabellifer L. * & Arecaceae & Tree & Panai maram &,$+ E$ \\
\hline 10. & Bulbostylis barbata (Rottb.) C.B. Clarke. (Image 3) & Cyperaceae & Herb & - & + \\
\hline 11. & Calotropis gigantea (L.) R.Br. & Asclepiadaceae & Shrub & Erukku &,$+ E$ \\
\hline 12. & Carica papaya L. & Caricaceae & Small Tree & Pappali & + \\
\hline 13. & Cassia italica (Mill.) Lam. ex F.W. Andrews. & Caesalpiniaceae & Herb & Nilavahai & $\mathrm{E}$ \\
\hline 14. & Casuarina litorea L. * & Casuarinaceae & Tree & Chavuku & $\mathrm{E}$ \\
\hline 15. & Catharanthus roseus (L.) G. Don. & Apocynaceae & Herb & Nithyakalyani & + \\
\hline 16. & Cenchrus ciliaris L. & Poaceae & Herb & Kolukattaipul & - \\
\hline 17. & Citrullus colocynthis (L.) Schrad. (Image 4) & Cucurbitaceae & Herb & Peykkumatti & + \\
\hline 18. & Cocos nucifera L. & Arecaceae & Tree & Thennai maram & $E$ \\
\hline 19. & Croton bonplandianus Baill. & Euphorbiaceae & Herb & Mannannai chedi & $\mathrm{E}$ \\
\hline 20. & Datura metel L. & Solanaceae & Herb & Oomathai & + \\
\hline 21. & Euphorbia hirta L. & Euphorbiaceae & Herb & Amampatchaiarisi & + \\
\hline 22. & Euphorbia tortilis Rottler ex Ainslie. & Euphorbiaceae & Shrub & Tirukukalli & - \\
\hline 23. & Fimbristylis cymosa R.Br. * (Image 5) & Cyperaceae & Herb & - & $\mathrm{E}$ \\
\hline 24. & Gisekia pharnaceoides L* (Image 6) & Aizoaceae & Herb & Manalkeerai &,$+ E$ \\
\hline 25. & Gomphrena serrata L. & Amaranthaceae & Herb & - & - \\
\hline 26. & Hibiscus tiliaceus L. * & Malvaceae & Tree & Neerparuthi & $\mathrm{E}$ \\
\hline 27. & Launaea intybacea (Jacq.) Beauverd. * & Asteraceae & Herb & - & + \\
\hline 28. & $\begin{array}{l}\text { Launaea sarmentosa (Willd.) Sch.Bip.ex Kuntze* } \\
\text { (Image 7) }\end{array}$ & Asteraceae & Herb & - & $\mathrm{E}$ \\
\hline 29. & Leucas aspera (Willd.) Link. & Lamiaceae & Herb & Thumbai & + \\
\hline 30. & Opuntia stricta (Haw.) Haw. & Cactaceae & Shrub & Sappathikalli & + \\
\hline 31. & Panicum repens L. * & Poaceae & Herb & - & - \\
\hline 32. & Passiflora foetida L. & Passifloraceae & Climber & Sirupunaikali & + \\
\hline 33. & Pedalium murex L. (Image 8) & Pedaliaceae & Herb & Perunerunji & - \\
\hline 34. & Phyla nodiflora (L.) Greene. & Verbenacee & Herb & Koduppai & + \\
\hline 35. & Prosopis juliflora (Sw.) DC. & Mimosaceae & Tree & Veelikkaruvai & $\mathrm{E}$ \\
\hline 36. & Pycreus polystachyos (Rottb.)P. Beauv* & Poaceae & Herb & & - \\
\hline 37. & Sida cordifolia L. & Malvacece & Herb & Nilathuthi & + \\
\hline 38. & Spinifex littoreus (Burm.f.) Merr. ${ }^{*}$ & Poaceae & Herb & Ravanan meesai & + \\
\hline 39. & Tephrosia purpurea (L.) Pers. & Fabaceae & Under Shrub & Kolingi & + \\
\hline 40. & Thespesia populnea (L.) Sol. ex Correa. * & Malvaceae & Tree & Poovarasu & + \\
\hline 41. & Tribulus terrestris $\mathrm{L}$. & Zygophyllaceae & Herb & Nerinji & + \\
\hline 42. & Vernonia cinerea (L.) Less. & Asteraceae & Herb & Mukuttipundu & + \\
\hline
\end{tabular}

E - Economic values; + - Medicinal values; * - Typical CSD plants. 


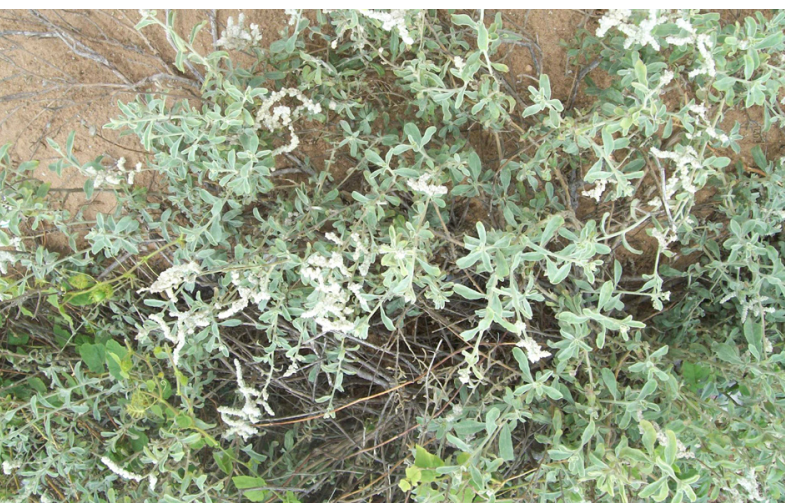

Image 2. Aerva persica

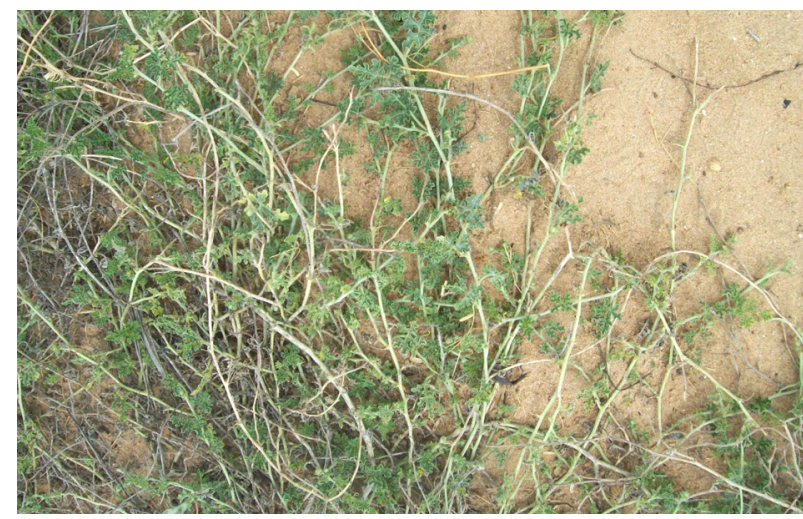

Image 4. Citrullus colocynthes

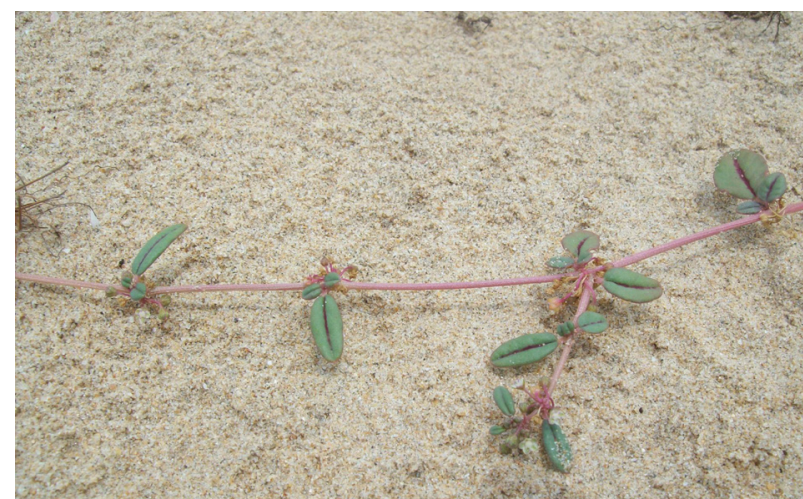

Image 6. Gisekia pharnaceoides

the study area preserves a rich floral diversity with a high number of sand dune medicinal plants, because during the survey 25 medicinal plants were found in the two small sample sites, Manapadu and Kulasakarapattanam. In addition, the different vegetation formations together with the dune field geomorphologic heterogeneity provide a wide variety of environmental conditions and habitat types.

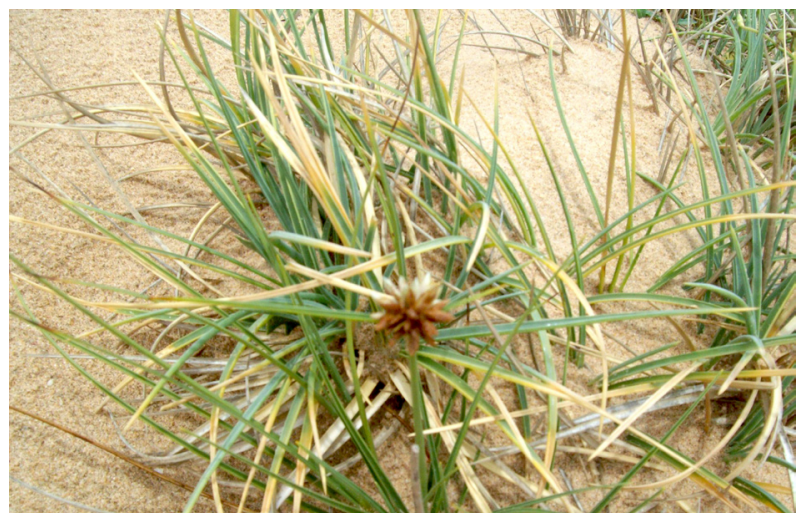

Image 3. Bulbostylis barbata

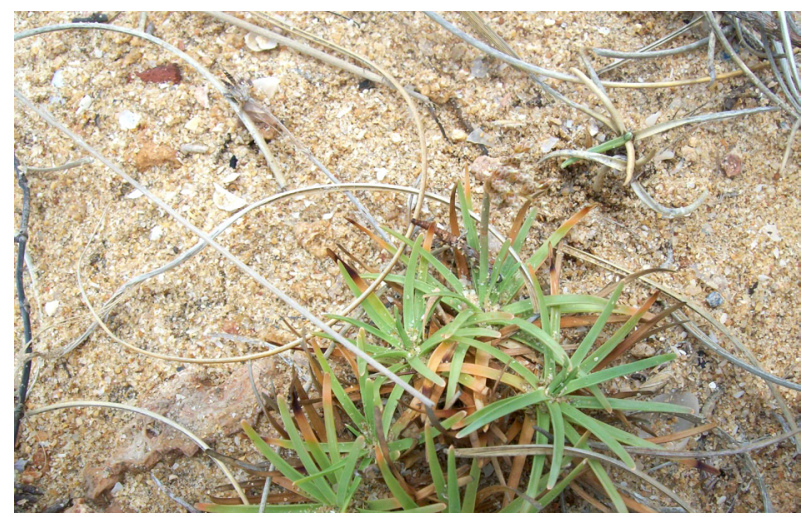

Image 5. Fimbristylis cymosa

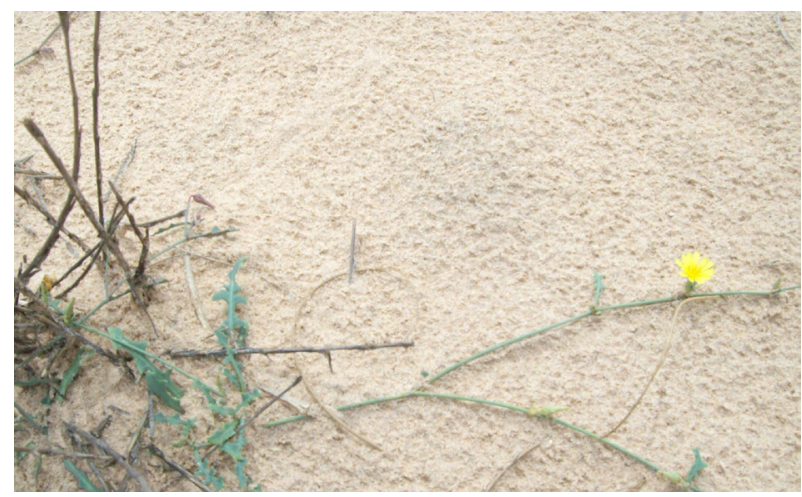

Image 7. Launaea sarmentosa

We also compared the floristic composition of the two coastal sites, Manapadu and Kulasakarapattanam. Among these two sites Manapadu had 31 species compared to Kulasakarapattanam which had 22 species. The species composition varied across these two sites. Species such as Fimbristylis cymosa, Spinifex littoreus, Launaea intybacea, were only found in the high tide line in both the sites. 


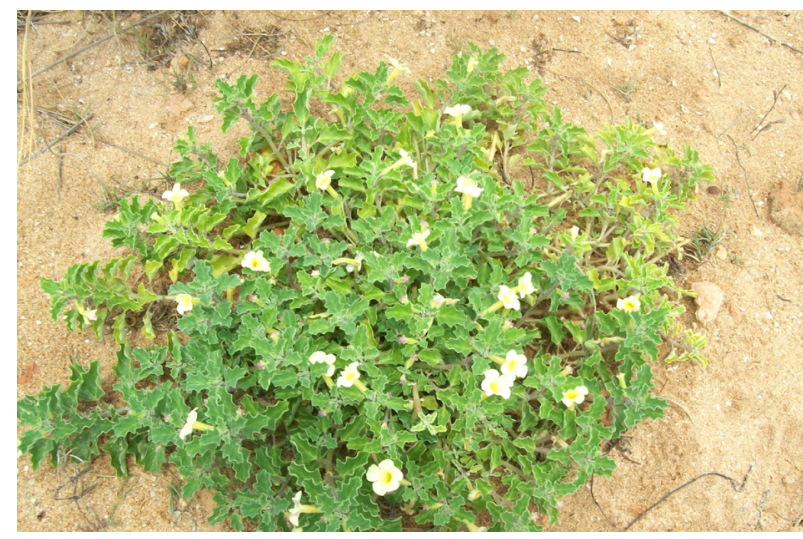

Image 8. Pedalium murex

Coastal sand dunes have been valued as an important coastal ecosystem offering protection to the hinterland, in maintaining the water table of coastal areas and even protecting the coastal agriculture from the salt laden winds blowing from the sea (Namboothri et al. 2008). Dunes are known to prevent intrusion of saltwater into the fresh aquifers of coastal areas. Coastal sand dunes are also important in maintaining the groundwater level of coastal areas, which is essential to sustain not only the flora and fauna, but also to provide an important source of freshwater for coastal populations. The dunes are occupied by a highly adapted group of plants specially suited to life in such harsh conditions. Critical to the formation, stabilisation and post-storm recovery process, is the presence of specialised dune plants e.g. Spinifex littoreus. These plants are capable not only of maintaining dune stability but can also colonize patches of bare sand and grow quickly down an eroded dune face to help build and restore the dune profile. Spinifex littoreus are very effective in long-term control of coastal erosion as they can grow to keep up with the movement of sand whereas rigid walls and structures are soon buried or undermined. Spinifex littoreus is a sand binding grass found on coastal fore dunes throughout the region. It is one of the few plants able to colonise the seaward face of the fore dune, and it is also considered as a berm to front dunes; primary stabilising plants consisting mainly of herbaceous species, were recorded. This area was composed of herbaceous species like Leucas aspera, Gisekia pharnaceoides, Tephrosia purpurea, coastal tree species like Borassus flabellifer and the introduced Casuarina equisitifolia.

Very often extensive sand dune systems may have interdunal sand dunes which are also closely integrated to the socioeconomic life of the coastal population. In Manapadu, coastal villages have a high level of sand dune formation and rich floral diversity as a single quadrate of $5 \times 5 \mathrm{~m}$ harbored 10 different species, which was much higher when compared to the other sand dune areas like Tiruchendur, Kayalpattanam and Kulasekarapattanam of Thoothukudi coast. A very good example of this is the Borassus flabellifer $L$. which is quite common on the sand dunes of southern Tamil Nadu. Before sugar was introduced into markets in India, B. flabellifer was a major plantation in southern Tamil Nadu from which jaggery was extracted. Jaggery was not only a major substitute for sugar, it was also a major source of livelihood for the coastal community of southern Tamil Nadu. In another example of Spinifex littoreus (Burm.f.) Merr., the extract from the grass was found to be very effective against bacteria and some fungi strains (Thirunavukkarasu et al. 2010) and this species is also very common. Nine species of Spinfex and five species of Fimbristylis were found, these are also excellent sand binders with medicinal value. Dried grass is used as fuel by fishermen and dry female inflorescence can be used for interior decoration (Daniel \& Umamaheswari 2001). Important religious sites were observed during the study. During religious celebrations floral diversity and environmental conditions were affected as human waste, polythene bags, and other solid wastes were deposited on the sand dunes. After the celebrations medicinal herbs and climbers were found destroyed. It is important to initiate efforts to conserve the floral diversity with the help of local communities through awareness creation.

\section{REFERENCES}

Anonymous (1987). Mangroves in India: Status Report, (Government of India, Ministry of Environment \& Forests, New Delhi, 1-150pp.

Arun, A.B., K.R. Beena., N.S. Raviraja \& K.R. Sridhar (1999). Coastal sand dunes - a neglected ecosystem. Current Science 77: 19-21.

Banerjee, L.K., T.A. Rao., A.R.K. Sastry \& D. Ghosh (2002). Diversity of Coastal Plant Communities in India. Botanical Survey of India, Kolkata, pp. 233-237 \& 319-320.

Barbour, M.G., T.M. de Jong \& B.M. Palvik (1985). Marine beach and dune plant communities. Physiological ecology of North American communities. Restoration Ecology 6: 
59-68.

Celsi, C.E. \& A.L. Monserrat (2008). Vascular plants, coastal dunes between Pehuen-có and Monte Hermoso, Buenos Aires, Argentina. Check List 4(1): 37-46.

Corre, J.-J. (1991). The Sand dunes and their vegetation along the Mediterranean coast of France. Their likely response to climate change. Landscape Ecology 6(1\&2): 65-72.

Daniel, P. \& P. Umamaheswari (2001). The Flora of Gulf of Mannar. Southern India. Botanical Survey of India, 605pp.

Desai, K.N. (2000). Dune vegetation: need for a reappraisal. Coastin (A Coastal Policy Rese Newsletter) 3: 6-8.

Fontana, S.L. (2005). Coastal dune vegetation and pollen representation in south Buenos Aires Province, Argentina. Journal of Biogeography 32: 719-735.

Forest Survey of India (2005). Electronic version report available at http://www.fsi.org.in/sfr2005. Accessed on 20 October 2010.

Grootjans, A.P., E.B. Adema., R.M. Bekker \& E.J. Lammerts (2004). Why young coastal dune slacks sustain a high biodiversity, pp. 85-101. In: Martinez, M.L. \& N.P. Psuty (eds.). Coastal Dunes, Ecology and Conservation. Berlin: Springer-Verlag.

Indian Meteorological Department (2009). Electronic Statistical report available at http://www.thoothukudi.nic.in accessed on 20 October 2010.

Koske, R.E. \& J.N. Gemma (1997). Mycorrhizae and succession in plantings of beach grass in sand dunes. American Journal of Botany 84: 118-130.

Kulkarni, S.S., N.S. Raviraja \& K.R. Sridhar (1997). Arbuscular mycorrhizal fungi of tropical sand dunes of west coast of India. Journal of Coastal Research 13: 931-936.

Kumar, M., E. Goossens \& R. Goossens (1993). Assessment of sand dune change detection in Rajasthan (Thar) Desert. International Journal of Remote Sensing 14(9): 16891703

Martinez, M.L., P. Moreno-Casasola \& G. Vazquez (1997). Effects of disturbance by sand movement and inundation by water on tropical dune vegetation dynamics. Canadian Journal of Botany 75: 2005-2014.

Maun, M.A. \& P. R. Baye (1989). The ecology of Ammophila breviligulata Fern. On coastal dune ecosystem. CRC Critical Reviews in Aquatic Science 1: 661-681.

Musila, W.M., J. I. Kimyamario \& P.D. Jungerius (2001). Vegetation dynamics of coastal sand dunes near Malindi, Kenya. African Journal of Ecology 39: 170-177.

Namboothri, N., D. Subramanian, B. Muthuraman \& A. Sridhar (2008). Policy Brief: Sand Dunes. Ashoka Trust for Research in Ecology and the Environment, Bangalore, India, 1-2pp.

Rao, T.A. \& A.N. Sherieff (2002). Coastal Ecosystem of the Karnataka State, India II - Beaches. Bangalore: Karnataka Association for the Advancement of Science, 250pp.

Sridhar, K.R. \& B. Bhagya (2007). Coastal sand dune vegetation: a potential source of food, fodder and pharmaceuticals. Electronic database available at http://www.lrrd.org/ lrrd19/6/srid19084. htm. Accessed on 20 October 2010.

Thirunavukkarasu, P., T. Ramanathan., L. Ramkumar \& T. Balasubramanian (2010). Anti Microbial Effect of a Coastal Sand Dune Plant of Spinifex littoreus (Burm. f.) Merr. Current Research Journal of Biological Sciences 2(4): 283-285.

Wagner, R.H. (1964). The Ecology of dunes - strand habitat of North Carolina. Ecological Monogarphs 34: 79-96. 